\title{
Plasma Aldosterone, Cortisol and Electrolyte Concentrations in Physical Exercise after Magnesium Supplementation
}

\author{
By S. W. Golf, O. Happel ${ }^{1}$, V. Graef \\ Institut für Klinische Chemie und Pathobiochemie an den Universitätskliniken \\ der Justus-Liebig-Universität Gießen and
}

\section{K. E. Seim}

Zentrum für Innere Medizin an den Universitätskliniken der Justus-Liebig-Universität Gießen

(Received June 4/August 17, 1984)

In honour of Prof. Dr. Ladislaus Róka on the occasion of his sixtyfifth birthday

\begin{abstract}
Summary: Plasma aldosterone, cortisol, sodium (Na), potassium $(\mathrm{K})$, calcium $(\mathrm{Ca})$, magnesium $(\mathrm{Mg})$ as well as urine and sweat $\mathrm{Na}, \mathrm{K}, \mathrm{Ca}$ and $\mathrm{Mg}$ concentrations were measured in nine male healthy persons during an one hour ergometer exercise before and after a fourteen day magnesium aspartate $(\mathrm{Mg})$ supplementation. The usual aldosterone and cortisol increase during exercise was not observed and cortisol concentration was significantly lower after $\mathrm{Mg}$ supplementation. $\mathrm{Na}$ and $\mathrm{K}$ in plasma increased during the exercise; these changes were not affected by $\mathrm{Mg}$. The $\mathrm{Mg}$ concentration was elevated in plasma and erythrocytes after $\mathrm{Mg}$ supplementation. During the ergometer course plasma $\mathrm{Mg}$ was unchanged but decreased significantly in the red blood cells. $\mathrm{Mg}$ and $\mathrm{K}$ concentration in sweat decreased during the exercise. No influence of $\mathrm{Mg}$ on urinary electrolyte excretion was observed.
\end{abstract}

Aldosteron-, Cortisol- und Elektrolytkonzentrationen im Plasma bei körperlicher Belastung unter Magnesiumsubstitution

Zusammenfassung: Die Konzentrationen von Cortisol, Aldosteron, Natrium (Na), Kalium (K), Calcium (Ca) und Magnesium (Mg) im Plasma sowie die Konzentrationen von $\mathrm{Na}, \mathrm{K}, \mathrm{Ca}$ und $\mathrm{Mg}$ im Urin und Schweiß wurden bei neun männlichen, gesunden Personen vor und nach einer 14tägigen Substitution mit MagnesiumAspartat $(\mathrm{Mg})$ währeñ körperlichen Belastung gefundene Anstieg des Aldosterons und Cortisols im Plasma wurde bei den mit Magnesium substituierten Personen nicht gefunden. Die Cortisol-Konzentration im Plasma war nach der MgSubstitution signifikant niedriger. Na und $\mathrm{K}$ im Plasma stiegen während der Belastung unabhängig von der $\mathrm{Mg}$-Substitution an. Die Mg-Konzentration im Plasma und in den Erythrocyten stieg unter der Mg-Substituțion an. Während der Ergometerbelastung änderte sich die $\mathrm{Mg}$-Konzentration im Plasma nicht, während sie in den roten Blutzellen signifikant abfiel. Die Konzentrationen von $\mathrm{Mg}$ und $\mathrm{K}$ im Schweiß sanken während der Belastung. Ein Einfluß der Mg-Substitution auf die Elektrolytausscheidung im Urin wurde nicht beobachtet.

\section{Introduction}

The pituitary-adrenocortical system is known to react to muscular exercise. Cortisol, for example, may be elevated in plasma if the duration of the ex-

1) This paper will be part of the doctoral thesis of $O$. Happel. ercise is long enough (1) and its increase is directly related to the intensity of the exercise $(2,3)$. The aldosterone elevation during exercise (4) is connected with the observed changes in renal function (5). Urine flow and sodium excretion are reduced following exercise (6). 
An elevation in plasma aldosterone is reported to increase urinary excretion of potassium and reabsorption of sodium (7) after prolonged exercise (5), although the human body seems to be able to maintain a stable fluid and electrolyte balance after prolonged exercise (5).

$\mathrm{Mg}$ is known to affect muscle metabolism and muscle cell permeability during exercise, as indicated by changes in plasma creatine kinase activities (EC 2.7.3.2) (8).

The present experiments were designed to study the effects of $\mathrm{Mg}$ on the adrenocortical hormones in plasma during exercise under controlled conditions.

\section{Methods}

Nine healthy, male subjects (18-40 years, normal eating habits) received $15 \mathrm{mmó}$ magnesium- $L$-aspartate-hydrochloride (Magnesiocard ${ }^{\circledR}$-Granulat, Verla Pharm, D-8132 Tutzing) daily for a 14 day period. Before and after the magnesium supplementation each person performed a rigorously identical 1 hour ergometer exercise. In order to perform the study under comparable conditions for the different subjects, the intensity of work was adjusted to their individual weight and age, starting at 70 to 100 watt increasing by steps of 10 to 20 watts every ten minutes. Electrocardiograms were recorded continuously. A 21-gauge butterfly needle was placed in a superficial vein of the arm in order to obtain blood without stasis in 20 minutes intervals. Sweat was taken during the exercise whenever possible. Before and at the end of the magnesium supplementation period a $24 \mathrm{~h}$ urine was collected from each subject.

$\mathrm{Na}, \mathrm{K}$ and $\mathrm{Ca}$ were determined by flame photometry (Eppendorf AFM 5051), Mg by atomic absorption photometry (Evans Electroselenium, Sussex, U.K.). Aldosterone was determined using a radioimmunoassay kit obtained from Isotopendienst West, Sprendlingen, Germany. Antiserum for the radioimmunological determination of cortisol was purchased from Panchem, D-8751 Kleinwallstadt. The cross reaction with other steroids normally occurring in plasma was less than $2.25 \%$ in the radioimmunoassays.

The coefficients of variation (quality control for between-assay variation) for the above methods were $1.3 \%, 1.9 \%, 1.6 \%, 1.9 \%$, $5.6 \%$ and $8.1 \%$, respectively.

The statistical evaluation was carried out using the two factorial analysis of variance with repeated measures and the t-test with paired data.

\section{Results and Discussion}

During the 14 days of magnesium supplementation, the plasma $\mathrm{Mg}$ concentration and the $\mathrm{Mg}$ content of the erythrocytes increased significantly by $8 \%(\mathrm{P}<$ $0.005)$ and $27 \%(\mathrm{P}<0.025 \%)$, respectively (tab. 1$)$. Urine excretion of $\mathrm{Mg}$ was unchanged before and during the $\mathrm{Mg}$ supplementation, an indication that the absorbed magnesium was taken up by the cells.
A significant increase of $\mathrm{Mg}$ excretion in urine is usually observed only after prolonged $\mathrm{Mg}$ intake. In several reports $(9,10,11)$ no significant elevation of $\mathrm{Mg}$ concentration in urine could be observed even after 14 days of $\mathrm{Mg}$ supplementation.

During the exercise, the magnesium concentration of the plasma remained unchanged, while the $\mathrm{Mg}$ erythrocyte concentration decreased in the control and the $\mathrm{Mg}$ group by $20 \%$ and $27 \%$ (tab. 1). The loss of magnesium in the sweat (792 and $733 \mathrm{ml}$ ) during the course of the excercise, which was paralleled by a corresponding weight loss, was $0.36 \mathrm{mmol}$ in the control and $0.59 \mathrm{mmol}$ in the magnesium group. As the amount of $\mathrm{Mg}$ lost by the erythrocytes was much larger $(1.2 \mathrm{mmol})$ we must assume that $\mathrm{Mg}$ was taken up by tissues, for example by the muscle cells (12).

It seems that the magnesium ion shifts from the erythrocytes, which act as a reservoir, to the plasma, and from there to the tissues during the exercise. When the duration of the physical exercise is longer than one hour and involves more muscle tissues, a significant decrease of $\mathrm{Mg}$ concentration in plasma may occur (13), probably caused by an exhaustion of the erythrocyte reservoir.

There was quite a high loss of $\mathrm{Mg}$ into sweat, while the $\mathrm{Mg}$ concentration in sweat dropped to $50 \%$ of the initial level during the course of the exercise (tab. 1). The reason for this $\mathrm{Mg}$ reduction in sweat (also observed for $\mathrm{K}$, but not for $\mathrm{Na}$ ) is not known and cannot be explained by corresponding changes in plasma aldosterone concentration. Our measured $\mathrm{Na}(110 \mathrm{mmol})$ and $\mathrm{K}(13 \mathrm{mmol})$ losses in sweat (both groups) do not agree with values reported by other investigators (14).

We must assume that a different ion shift from the cells or the interstitium to the plasma exists for $\mathrm{K}$; its concentration increased by $20 \%$ during the exercise. This is probably caused by a loss of cell potassium to the interstitium due to changes in $\mathrm{H}^{+},, \mathrm{K}^{+}$- and $\mathrm{Na}^{+}-$ ion transport across the cell membrane $(14,15)$ and a concomitant flow of the lymph with its high $\mathrm{K}$ concentration into the intravascular space (16).

The interactions between plasma potasssium and aldosterone are well known. It is assumed that the elevation of plasma aldosterone during exercise is caused by several factors. An increase in renin causes an increase in the production and plasma concentration of angiotensin $(17,18)$. Angiotensin in turn induces the secretion of aldosterone (19). The increase in plasma aldosterone may also be favoured by increases in plasma potassium (20) and corticotropin (21), but also by a decréáse in hepatic reduc- 
Tab. 1. Electrolyte, aldosterone and cortisol concentrations ( \pm standard deviation) in human plasma, sweat and urine during an ergometer exercise. Control: before $\mathrm{Mg}$ supplementation. $\mathrm{Mg}$ suppl: after a 14 day $\mathbf{M g}$ supplementation.

\begin{tabular}{|c|c|c|c|c|c|c|c|c|c|}
\hline & & \multicolumn{8}{|c|}{ Time of exercise (min) } \\
\hline & & 0 & & 20 & & 40 & & 50 & 60 \\
\hline $\begin{array}{l}\text { Heart rate } \\
\left(\min ^{-1}\right)\end{array}$ & $\begin{array}{l}\text { control } \\
\text { Mg suppl }\end{array}$ & $\begin{array}{l}91 \\
85\end{array}$ & $\begin{array}{l} \pm 10 \\
\pm 18\end{array}$ & $\begin{array}{ll}126 & \pm \\
118 & \pm\end{array}$ & $\begin{array}{l} \pm 14 \\
\pm 15\end{array}$ & $\begin{array}{l}146 \\
134\end{array}$ & $\begin{array}{l} \pm 16 \\
\pm 20\end{array}$ & & $\begin{array}{ll}164 & \pm 17 \\
149 & \pm 24\end{array}$ \\
\hline $\begin{array}{l}\mathrm{Mg}(\mathrm{mmol} / \mathrm{l}) \\
\text { in plasma }\end{array}$ & $\begin{array}{l}\text { control } \\
\text { Mg suppl }\end{array}$ & $\begin{array}{l}0.79 \\
0.85\end{array}$ & $\begin{array}{l} \pm 0.07 \\
\pm \quad 0.19\end{array}$ & $\begin{array}{l}0.81 \pm \\
0.81 \pm\end{array}$ & $\begin{array}{l}0.08 \\
\pm \quad 0.12\end{array}$ & $\begin{array}{l}0.82 \\
0.89\end{array}$ & $\begin{array}{l} \pm 0.12 \\
\pm \quad 0.23\end{array}$ & & $\begin{array}{l}0.83 \pm 0.13 \\
0.83 \pm 0.15\end{array}$ \\
\hline $\begin{array}{l}\mathrm{Mg}(\mathrm{mmol} / \mathrm{l}) \\
\text { in erythrocytes }\end{array}$ & $\begin{array}{l}\text { control } \\
\mathrm{Mg} \text { suppl }\end{array}$ & $\begin{array}{l}3.01 \\
3.83\end{array}$ & $\begin{array}{l} \pm 0.86 \\
\pm \quad 2.09\end{array}$ & $\begin{array}{l}3.03 \pm \\
3.06 \pm\end{array}$ & $\begin{array}{l} \pm 0.68 \\
\pm \quad 0.72\end{array}$ & & & & $\begin{array}{l}2.41 \pm 0.75 \\
3.19 \pm 0.80\end{array}$ \\
\hline $\begin{array}{l}\mathrm{Ca}(\mathrm{mmol} / \mathrm{l}) \\
\text { in plasma }\end{array}$ & $\begin{array}{l}\text { control } \\
\text { Mg suppl }\end{array}$ & $\begin{array}{l}2.43 \\
2.41\end{array}$ & $\begin{array}{l} \pm 0.06 \\
\pm 0.11\end{array}$ & $\begin{array}{l}2.43 \pm \\
2.44 \pm\end{array}$ & $\begin{array}{l}0.12 \\
0.12\end{array}$ & $\begin{array}{l}2.50 \\
2.48\end{array}$ & $\begin{array}{ll} \pm & 0.10 \\
\pm & 0.12\end{array}$ & & $\begin{array}{ll}2.54 \pm & 0.10 \\
2.50 \pm & 0.11\end{array}$ \\
\hline $\begin{array}{l}\mathrm{K}(\mathrm{mmol} / \mathrm{l}) \\
\text { in plasma }\end{array}$ & $\begin{array}{l}\text { control } \\
\text { Mg suppl }\end{array}$ & $\begin{array}{l}4.22 \\
4.10\end{array}$ & $\begin{array}{l} \pm 0.36 \\
\pm 0.23\end{array}$ & $\begin{array}{l}4.68 \pm \\
4.51 \pm\end{array}$ & $\begin{array}{l}0.16 \\
0.24\end{array}$ & $\begin{array}{l}4.91 \\
4.77\end{array}$ & $\begin{array}{l} \pm 0.25 \\
\pm 0.22\end{array}$ & & $\begin{array}{l}5.03 \pm 0.28 \\
4.90 \pm 0.38\end{array}$ \\
\hline $\begin{array}{l}\mathrm{Na}(\mathrm{mmol} / \mathrm{l}) \\
\text { in plasma }\end{array}$ & $\begin{array}{l}\text { control } \\
\text { Mg suppl }\end{array}$ & $\begin{array}{l}140.4 \\
139.7\end{array}$ & $\begin{array}{l} \pm 2.1 \\
\pm 2.5\end{array}$ & $\begin{array}{l}140.8 \pm \\
140.7 \pm\end{array}$ & $\begin{array}{r}2.4 \\
2.4\end{array}$ & $\begin{array}{l}141.6 \\
141.4\end{array}$ & $\begin{array}{l} \pm 2.5 \\
\pm 2.9\end{array}$ & & $\begin{array}{l}143.0 \pm 2.3 \\
141.3 \pm 2.4\end{array}$ \\
\hline $\begin{array}{l}\text { Aldosterone in } \\
\text { plasma (nmol/l) }\end{array}$ & $\begin{array}{l}\text { control } \\
\mathrm{Mg} \text { suppl }\end{array}$ & $\begin{array}{l}0.26 \\
0.38\end{array}$ & $\begin{array}{ll} \pm & 0.14 \\
\pm & 0.09\end{array}$ & $\begin{array}{l}0.40 \pm \\
0.23 \pm\end{array}$ & $\begin{array}{l}0.26 \\
0.18\end{array}$ & $\begin{array}{l}0.52 \\
0.25\end{array}$ & $\begin{array}{ll} \pm & 0.35 \\
\pm & 0.21\end{array}$ & & $\begin{array}{ll}0.53 \pm & 0.37 \\
0.33 \pm & 0.22\end{array}$ \\
\hline $\begin{array}{l}\text { Cortisol in } \\
\text { plasma ( } \mu \mathrm{mol} / \mathrm{l})\end{array}$ & $\begin{array}{l}\text { control } \\
\text { Mg suppl }\end{array}$ & $\begin{array}{l}0.27 \\
0.21\end{array}$ & $\begin{array}{l} \pm 0.07 \\
\pm \quad 0.01\end{array}$ & $\begin{array}{l}0.31 \pm \\
0.22 \pm\end{array}$ & $\begin{array}{l}0.10 \\
0.05\end{array}$ & $\begin{array}{l}0.26 \\
0.19\end{array}$ & $\begin{array}{l} \pm 0.09 \\
\pm 0.04\end{array}$ & & $\begin{array}{l}0.23 \pm 0.10 \\
0.18 \pm 0.04\end{array}$ \\
\hline $\begin{array}{l}\text { Mg in urine } \\
(\mathrm{mmol} / 24 \mathrm{~h})\end{array}$ & $\begin{array}{l}\text { control } \\
\text { Mg suppl }\end{array}$ & $\begin{array}{l}4.5 \\
4.2\end{array}$ & $\begin{array}{ll} \pm & 0.9 \\
\pm & 1.8\end{array}$ & & & & $\cdot$ & & \\
\hline $\begin{array}{l}\text { Na in urine } \\
(\mathrm{mmol} / 24 \mathrm{~h})\end{array}$ & $\begin{array}{l}\text { control } \\
\mathrm{Mg} \text { suppl }\end{array}$ & $\begin{array}{l}109.0 \\
113.9\end{array}$ & $\begin{array}{l} \pm 47.1 \\
\pm 30.0\end{array}$ & & & & & & \\
\hline $\begin{array}{l}\mathrm{K} \text { in urine } \\
(\mathrm{mmol} / 24 \mathrm{~h})\end{array}$ & $\begin{array}{l}\text { control } \\
\text { Mg suppl }\end{array}$ & $\begin{array}{l}56.8 \\
52.7\end{array}$ & $\begin{array}{l} \pm 12.6 \\
\pm 25.3\end{array}$ & & & & & & \\
\hline $\begin{array}{l}\text { Mg in sweat } \\
(\mathrm{mmol} / \mathrm{l})\end{array}$ & $\begin{array}{l}\text { control } \\
\text { Mg suppl }\end{array}$ & & & & & $\begin{array}{l}0.67 \\
0.72\end{array}$ & $\begin{array}{l} \pm 0.42 \\
\pm 0.36\end{array}$ & $\begin{array}{ll}0.42 \pm & 0.16 \\
0.53 \pm & 0.26\end{array}$ & $\begin{array}{l}0.34 \pm 0.11 \\
0.44 \pm 0.19\end{array}$ \\
\hline $\begin{array}{l}\text { Na in sweat } \\
(\mathrm{mmol} / \mathrm{l})\end{array}$ & $\begin{array}{l}\text { control } \\
\text { Mg suppl }\end{array}$ & & & & & $\begin{array}{l}140 \\
124\end{array}$ & $\begin{array}{l} \pm 63 \\
\pm 38\end{array}$ & 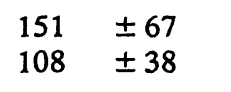 & 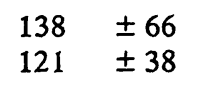 \\
\hline $\begin{array}{l}\mathrm{K} \text { in sweat } \\
(\mathrm{mmol} / \mathrm{l})\end{array}$ & $\begin{array}{l}\text { control } \\
\text { Mg suppl }\end{array}$ & & & & & $\begin{array}{l}17.5 \\
20.1\end{array}$ & $\begin{array}{l} \pm 4.9 \\
\pm \quad 5.7\end{array}$ & $\begin{array}{l}16.7 \pm 2.9 \\
19.4 \pm 5.8\end{array}$ & $\begin{array}{l}13.0 \pm 2.4 \\
15.4 \pm 6.9\end{array}$ \\
\hline $\begin{array}{l}\text { Weight loss } \\
\text { (g) }\end{array}$ & $\begin{array}{l}\text { control } \\
\mathrm{Mg} \text { suppl }\end{array}$ & & & & & & & & $\begin{array}{l} \pm 130 \\
\pm 171\end{array}$ \\
\hline
\end{tabular}

tion of aldosterone (21). The increase in plasma aldosterone during exercise was confirmed by our study (fig. 1).

After the 14 day magnesium supplementation no aldosterone increase in plasma during the exercise was observed (fig. 1). In contrast, a significant decrease $(P<0.05)$ in aldosterone concentration was measured after 20 minutes, which returned to almost normal values after 60 minutes. This is surprising, but similar observations have been made after the ingestion (22) and after the intravenous application (23) of an electrolyte solution.

The observed aldosterone decrease in plasma during the exercise (after Mg supplementation) may be explained by either a reduced production rate of aldosterone in the adrenal gland, by an increased metabolic clearance in the liver or by an increeased renal uptake of aldosterone. The normalization of aldosterone concentration at the end of the exercise (fig. 1)

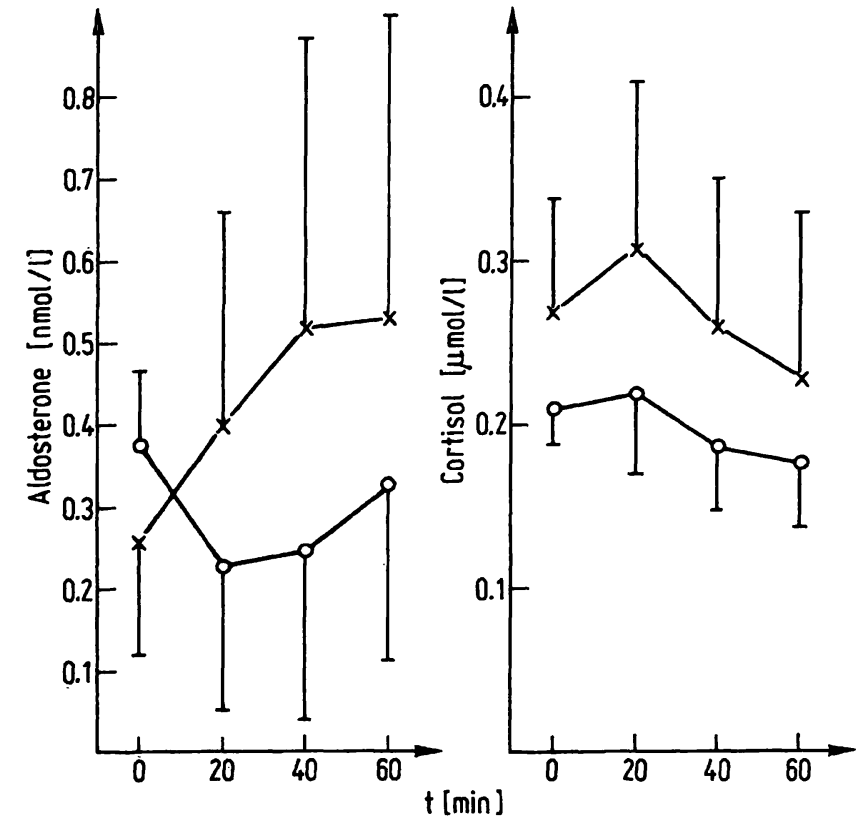

Fig. 1. Plasma aldosterone (a) and cortisol (b) concentrations during a 1 hour ergometer exercise in nine healthy male subjects. $-x-$ before, and $-O-$ after a 14 day magnesium supplementation. 
is evidence that the production rate of aldosterone is not affected. An increased metabolic clearance of aldosterone is also unlikely, since the hepatic blood flow drops during exercise (24). In addition, the steroid metabolizing enzyme systems in the liver, cortisone $5 \alpha$-reductase (EC 1.3.1.4), 3-oxo-5 $\alpha$-steroid: $\mathrm{NAD}^{+} \Delta^{4}$-oxidoreductase (EC 1.3.1.?) and cortisone $5 \beta$-reductase (EC 1.3.1.3) are not $\mathrm{Mg}$ dependent (25). If, however, the available NADH/NADPH pool in the liver increases following $\mathrm{Mg}$ supplementation an increased aldosterone reduction can result, but such an effect has not yet been described.

The third possible explanation for the plasma aldosterone decrease during exercise after $\mathrm{Mg}$ supplementation is an increased aldosterone uptake by tissues such as the kidney. During prolonged running, renal aldosterone uptake was reported to be increased and at the same time urinary sodium excretion decreased (5). We observed no effect of $\mathrm{Mg}$ supplementation on urinary $\mathrm{Na}$ and $\mathrm{K}$ excretion, but this was expected, since the aldosterone concentration in plasma at the beginning of the exercise was within the same range in both groups. If aldosterone uptake by the kidney during exercise is increased after $\mathrm{Mg}$ supplementation, then a reduced urinary sodium excretion shortly after the exercise should be expected.

Plasma cortisol was significantly lowered $(\mathrm{P}<$ 0.025 ) following magnesium supplementation and remained decreased during the exercise (fig. 1). The heart rate in the $\mathrm{Mg}$ group was significantly lower ( $\mathrm{P}$ $<0.03$ ) during the exercise (tab. 1). It is known that beside other hormones plasma cortisol concentra- tions may be increased by emotional or somatic stress $(26,27,28)$ and the different heart rates might be due to the difference in plasma cortisol concentrations in the two groups. In addition, it is known that $\mathrm{Mg}$ acts as a physiological $\mathrm{Ca}$ antagonist. However, we did not observe a corresponding increase during the exercise, with the exception of a significant cortisol elevation $(P<0.05)$ in the control group after 20 minutes (fig. 1). The plasma cortisol concentration reflects a steady state between cortisol production and elimination from plasma by tissue uptake. An increased cortisol production by the adrenal gland during exercise (2) is usually accompanied by an increased uptake of cortisol by the tissues (3). Several tissues, including the liver, are involved in cortisol uptake during exercise (29). Since the liver can be excluded as a source of increased cortisol elimination (for the same reasons that apply to the elimination of aldosterone), it is tempting to speculate that the skeletal muscles and the adipose tissues are responsible for the increased uptake of cortisol (3).

At present we cannot decide whether the evidence for a $\mathrm{Mg}$ induced increase of tissue uptake of cortisol and aldosterone by muscle, adipose tissue and kidney represents a specific process which responds to an increased demand for cortisol and aldosterone by the tissues during the exercise, or whether it reflects a general redistribution of cortisol and aldosterone associated with a redistribution of body water.

Our data show that $\mathrm{Mg}$ plays a certain role in aldosterone and cortisol metabolism; and provide evidence that $\mathrm{Mg}$ influences aldosterone and cortisol kinetics during exercise.

\section{References}

1. Brandenburger, G. \& Follenius, M. (1975) J. Clin. Endocrinol. Metab. 40, 845 .

2. Davies, C. T. M. \& Few, J. D. (1973) J. Appl. Physiol. 35, 887-891.

3. Few, J. D. (1974) J. Endocrinol. 62, 341-353.

4. Mahler, J., Jones, L., Hartley, L., Williams, G. \& Rose, L. (1975) J. Appl. Physiol. 39, 221-225.

5. Wade, C. E., Dressendorfer, R. H., O'Brien, J. C. \& Claybaugh, J. R. (1981) J. Appl. Physiol. 50, 709-712.

6. Castenfors, J. (1978) Ann. N.Y. Acad. Sci. 301, 151-159.

7. Knochel, J., Dotin, L. \& Hamburger, R. (1972) J. Clin. Invest. $51,242-255$.

8. Golf, S. W., Graef, V., Gerlach, H.-J. \& Seim, K. E. (1983) Magnesium-Bulletin 5, 43-46.

9. Alken, P., Herzog, P., Mappes, J., Holtermüller, K.-H. \& Dosch, W. (1981) Fortschr. Urol. Nephrol. 17, 366-371.

10. Terhorst, B. \& Jonas, D. (1974) Fortschr. Urol. Nephrol. 4, 81-85.

11. Jarrar, K., Graef, V. \& Bödeker, H. (1984) accepted for publication, Plenum Press.

12. Strömme, S. B., Stensvold, I. C., Meen, H. D. \& Revsum, H. E. (1975) in "Metabolic Adaptation to Prolonged Physical Exercise" (Howald, H. J. \& Poortmans, J. R., eds.) Wissenschaftl. Schriftenreihe, Forschungsinstitut der Eidgen. Turnund Sportschule Magglingen, Bd. 7.

13. Haralambie, G. (1979) Der Krạnkenhausarzt 52, 293-299.

14. Hollmann, W. \& Hettinger, Th. (1980) in ,Sportmedizin Arbeits- und Trainingsgrundlagen", K. Schattạuer Verlag, Stuttgart, New York, p. 77.

15. Gebert, G. (1972) Pflügers Arch. Ges. Physiol. 331, 204214.

16. Tibes, U. \& Hemmer, B. (1973) Pflügers Arch. Ges. Physiol. 339, Suppl. R 27.

17. Maher, J. T., Jones, L. G., Hartley, L. H., 'Williams, G. H. \& Rose, L. I. (1975) J. Appl. Physiol. 39, 18-22.

18. Mankem, P., Brammert, M., Hulten, U. L. \& Höckfeldt, B. (1981) Europ. J. Clin. Invest. 11, 389-395.

19. Bonelli, J., Waldhäusl, W., Magometschnigg, D., Schwaržmeier, J., Korn, A. \& Hitzenberger, G. (1977) Eur. J. Clin. Invest. 7, 337-343. 
20. Convertino, V. A., Brock, P. J., Keil, L. C., Bernauer, E. M. \& Greenleaf, J. E. (1980) J. Appl. Physiol. 48, 665-669.

21. Sundsfjord, J. A., Strömme, S. B. \& Aakvaag, A. (1975) in "Mctabolic Adaptation to Prolonged Physical Exercise" (Howald, H. \& Poortmans, J. R.. eds.) Birkhäuser Verlag, Basel, pp. 308-314.

22. Francis, K. T. \& MacGregor, R. (1978) Aviat. Space Environ. Med. 49, 461-465.

23. Pedersen, O., Beck-Nielsen, H. \& Heding, L. (1980) N. Eng. J. Med. 302, 886-892.

24. Rowell, L. B., Blackmon, J. R. \& Bruce, R. A. (1964) J. Clin. Invest. 43, 1677-1690.
25. Leybold, K. \& Staudinger, Hj. (1963) Biochem. Z. 337, 320-327.

26. Hartley, L. H., Mason, J. W., Hogan, R. P., Jones, L. G., Kotchen, T. A., Mougey, E. H., Wherry, F. E., Pennington, L. L. \& Ricketts, P. T. (1972) J. Appl. Physiol. 33, 607-610.

27. Sutton, J. R. (1981) Med. Sci. Sports Exercisc 13, 266-271.

28. Shephard, R. J. \& Sidney, K. H. (1975) Exercise and Sport Sci. Rev. 3, 1-30.

29. Rennie, M. J., Park, D. M. \& Sulaiman, W. R. (1976) Am. J. Physiol. 231, 967-973.

Dr. Sighart Golf Institut für Klinische Chemic und Pathobiochemie an den Kliniken der Justus-Liebig-Universität Gießen Klinikstraße 36 D-6300 Gießen 
" 